\title{
О МЕТОДОЛОГИИ ОЦЕНКИ КОНФОРМНОСТИ АТОМНО-СЛОЕВОГО ОСАЖДЕНИЯ ТОНКИХ ПЛЕНОК В ВЫСОКОАСПЕКТНЫХ НАНОСТРУКТУРАХ
} THE OUANTIFICATION OF THIN FILM ATOMIC LAYER
DEPOSITION CONFORMALITY IN HIGH ASPECT RATIO
NANOSTRUCTURES

DOI: $10.22184 / 1993-8578.2019 .12 .3-4.194 .204$

Получено: 20.12.2018 г.

В.Ю.Васильев, зам. генерального директора ООО "СибИС", г. Новосибирск, доктор химических наук, профессор, Новосибирский государственный технический университет (ORCID: 0000-0002-0657-4502) / vasilev@corp.nstu.ru V.Yu.Vasiliev, Deputy Director General, SibIS LLC, Novosibirsk, Doctor of Chemical sciences, Professor, Novosibirsk State Technical University, (ORCID: 0000-0002-0657-4502)

Рассмотрены проблемы и способы количественной характеризации конформности тонкопленочных покрытий на поверхностях высокоаспектных наноструктур при атомнослоевом осаждении (АСО). Автор развивает ранее предложенную методологию анализа конформности тонкопленочных покрытий методами химического и плазменного осаждения из газовой фазы, и АСО. Предложенная автором методология позволяет проводить адекватную оценку и количественное сравнение результатов для структур различной сложности при использовании различных методов и режимов получения тонких пленок методом АСО.

The problems and methods for the quantitative characterization of the conformality of thin films on the surfaces of high-aspect ratio nanostructures during atomic layer deposition (ALD) are considered. The author develops the previously proposed methodology for analyzing the conformity of thin films by chemical vapor deposition (CVD) and plasma-enhanced deposition (PECVD), and ALD. The methodology proposed by the author allows to perform an adequate assessment and quantitative comparison of the results for the device structures of varying complexity using different kinds and conditions of ALD method.

\section{ВВЕДЕНИЕ}

Движущей силой развития современных прецизионных технологических процессов являются технологии интегральных микросхем (ИМС) [1]. По мере их динамичного развития и усложнения интенсивно разрабатывались технологии и оборудование для создания тонкопленочных материалов различной природы (диэлектрики, полупроводники, металлы и т.д.) [2]. В технологиях ИМС тонкие пленки (ТП) являются основным конструкционным материалом для формирования изолированных транзисторных структур, конденсаторов, резисторов, системы многоуровневой металлизации и финишной пассивации. Тонкие пленки получают на нагретых до необходимой температуры поверхностях подложек различных типов, главным образом методами химического осаждения из газовой фазы (ХОГФ) как результат необратимых реакций исходных парообразных веществ. Реакции ХОГФ при пониженных температурах могут быть дополнительно активированы, например, плазменным разрядом. Основные тренды развития методов ХОГФ применительно к технологии ИМС рассмотрены в [3] начиная с начала 1970-х годов по настоящее время. В частности, были выделены временные этапы развития методов ХОГФ и для каждого из них рассмотрены задачи, направления развития, обобщены результаты исследований и разработок оборудования, процессов осаждения, свойств ТП.

Главной задачей для методов ХОГФ на первом этапе их развития было получение равномерных по толщине покрытий на практически плоской 
поверхности подложек монокристаллического кремния, причем все более и более возрастающего размера. Начиная со второго этапа развитие ИМС пошло по пути формирования элементов ИМС на поверхности полупроводниковых подложек (рис.1). В рельефах таких трехмерных ИМС в качестве типичных упрощенных структур можно выделить ступеньки (рис.2а) и канавки (отверстия), рис.2b. Такие упрощенные структуры характеризуют величиной т.н. "аспектного отношения" (Aspect Ratio, AR). Под аспектным отношением в наиболее принятом случае подразумевается отношение высоты/глубины канавки (Н, мкм) к ее ширине или диаметру (G, мкм).

Использование ХОГФ на трехмерных рельефах ИМС обнаружило проблемы неравномерности роста ТП, которые фиксируются путем анализа сколов тестовых структур с ТП с помощью растровых электронных микроскопов (РЭМ). Оказалось, что на ступенчатых структурах имеет место неприемлемое для технологии ИМС уменьшение толщины покрытий от верхних внешних частей структур в их глубину. Такую неравномерность ТП на рельефе характеризуют термином "конформность" и выражают как процентное отношение толщины ТП в нижней части канавки на внутренней боковой поверхности $\left(\mathrm{d}_{2}\right)$ к таковой на ее верхней плоской поверхности

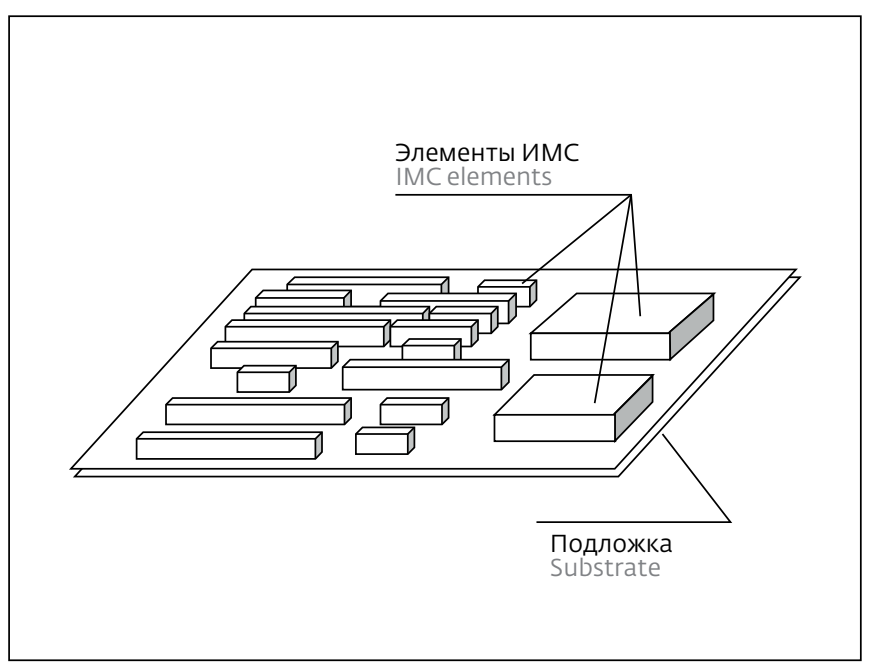

Puc.1. Упрощенная схема чипа с элементами ИМС на поверхности подложки

Fig.1. Simplified scheme of a chip with IMC elements on the substrate surface

$\left(\mathrm{d}_{1}\right)$, рис.2а. По результатам исследований для разных процессов ХОГФ конформность ТП $\left(\mathrm{d}_{2} / \mathrm{d}_{1}\right.$, \%) может изменяться от 100 \% в верхней части канавок вплоть до нуля (т.е. - разрыва сплошности материала) в нижней их части.

\section{INTRODUCTION}

The integrated microcircuit technology [1] is the driving force behind the development of modern precision technological processes. As these processes dynamically develop and the technologies become more complicated, the technique and equipment for thin film materials fabrication of different nature (dielectrics, semiconductors, metals, etc.) have been intensively developed [2]. In integrated circuit technologies (ICT) thin films (TF) are the basic construction material to prepare insulated transistor structures, capacitors, resistors, multilevel metal coating system and final etching. Thin films have been prepared on substrates of different types heated to the required temperature, mainly by chemical vapor deposition method as a result of irreversible reactions of initial vaporous substances. Reactions at CVD process at depressed temperature levels could be activated by plasma discharge. Main trends of CVD methods development applied to ICT from the 1970 s till present time have been considered [3]. Particularly, the time stages of CVD methods development and tasks were identified and directions of the development, research results and TF properties for each one were generalized. At first stage the main task of CVD methods was to provide uniform thickness coatings on an almost flat surface of Si-substrates, more and more increasing in size. Starting from the second stage the IST development began with the formation of ICT elements on semiconductor substrates (see Fig.1). It is possible to distinguish steps (see Fig.2a) and grooves (holes) (see
Fig.2b) as typical simplified structures in reliefs of 3D integrated micro circuits (IMC). Such simplified structures can be characterized using the value known as "aspect ratio" (AR). In general, aspect ratio is the ratio of height or depth of the groove $(\mathrm{H}, \mu \mathrm{m})$ to its width or diameter $(\mathrm{G}, \mu \mathrm{m})$.

Usage of CVD on 3D reliefs of IMC revealed the problems connected with irregularities of thin films growth observed with a scanning electron microscope (SEM) during analysis of testing system edge splintering contained thin films. It was discovered that in case of step structures the reduction of coating thickness occurs from upper outer structure parts to its depth, which is almost unacceptable for IMC production. Such irregularity in TF relief is called "conformity" and characterized as percent ratio 


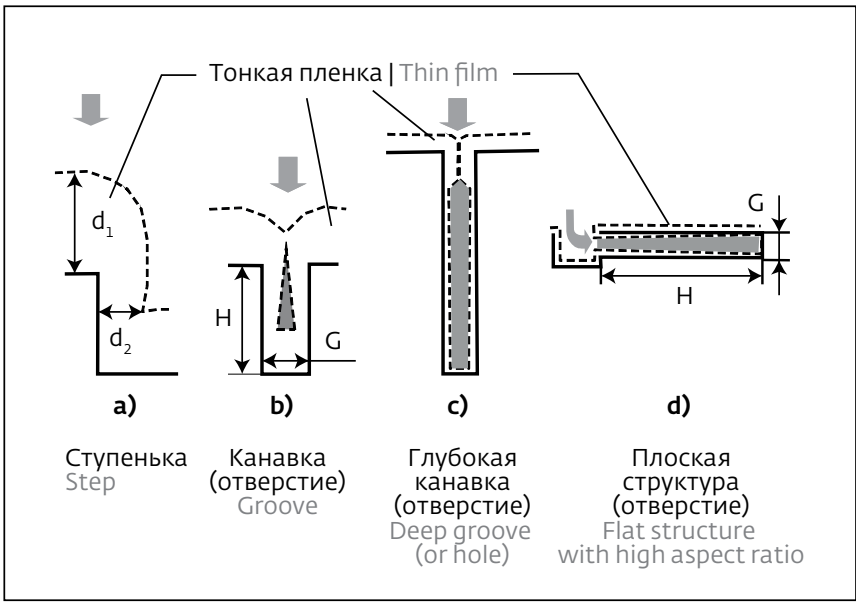

Рис. 2. Упрощенные схемы основных типов элементов рельефа ИМС: $a$ - ступенька, b - канавка, c - глубокая канавка (или отверстие), $d$ - плоская структура с большим аспектным отношением. Темным цветом показаны незаполненные материалом элементы канавок - пустоты. Блочными стрелками показано направление поступления газовой смеси к структуре

Fig.2. Simplified schemes of basic types of IMC element relief: $a$ - step, b - groove, c - deep groove (or hole), $d$ - flat structure with high aspect ratio. Dark colour indicates groove elements not filled with the material (voids). Arrows indicate the direction of gas mixture suuplied to the structure

На третьем этапе развития технологий ТП (примерно в середине 1990-х годов) возникла актуальная для субмикронных ИМС проблема качественного "безпустотного" заполнения зазоров в канавках рельефа ИМС. Суть проблемы, известной в зарубежной литературе под термином "voiding", состоит в том, что при неконформном росте ТП внутри канавок появляются неприемлемые для технологии ИМС пустоты (см. рис.2b). Описываемые проблемы усугубляются динамичным развитием и усложнением технологий ИМС, которые приводят к появлению рельефов с повышенными величинами AR. При этом очевидным является тот факт, что заполнение прямоугольных в сечении рельефов без пустот возможно только в случае идеальной $100 \%$ конформности роста ТП на всех поверхностях структур.

Различные аспекты решения проблем конформности и заполнения пустот рельефа при ХОГФ на этом этапе рассмотрены автором с соавторами в работах [3-6]. Суть развиваемого автором эмпирического подхода к обобщению результатов исследований конформности ТП состояла в попытке найти количественные взаимосвязи конформности ТП и характеристик структур и условий ХОГФ. Было проанализировано около 200 оригинальных публикаций из разных информационных источников, из которых были отобраны публикации, содержащие либо количественные данные (величины конформности, AR и G), либо фотографии структур с ТП и масштабом, позволяющие сделать такие оценки. Собственные исследования автора в этот период времени выполнялись на тестовых структурах субмикронных ИМС с высотой ступенек порядка микрометра. Исследования проведены для различных процессов ХОГФ ТП, большей частью - ТП на основе диоксида кремния. Процессы осаждения были количественно охарактеризованы of TF thickness in the lower part of the groove on the inner side surface $\left(\mathrm{d}_{2}\right)$ to its thickness at upper flat part $\left(\mathrm{d}_{1}\right)$, (see Fig.2a). According to research of different $C V D$ processes a TF conformity $\left(d_{2} / d_{1}, \%\right)$ may change from $100 \%$ in upper part of grooves up to zero (i.e., discontinuity of the material) in its lower part.

At the third stage of the IMC technologies development (in the middle of 1990s) the problem of "voids-free" quality filling of gapes on grooves of IMC relief (relevant for sub-micron IMC) has emerged. The problem known as "voiding" is that in case of irregular TF growth the unacceptable for IMC technologies voids appear (see Fig.2b). Moreover, problems described above are compounded due to development and complication of modern IMC technologies, which lead to appearance of reliefs with high values of aspect ratio (AR). Obviously, filling of rectangular cross section reliefs without voids is possible only in $100 \%$ of conformity value of TF growth on all structure surfaces.

Different ways of solving problems of conformity and filling of relief's voids at CVD at this stage were discussed by author with coauthors in [3-6]. The main idea of the author's empirical method of summary of results of TF investigations is to find out quantitative interrelations between TF conformity and structure characteristics and conditions of CVD processes. Analyzed were about 200 original publications from different sources in order to select a quantitative data (values of conformity, AR and G) or photos of TF structures with scale which allows such estimates to be made. The author's own research at the time was made on test structures of submicron IMC with height of steps of the order of a micrometer. Studies have been carried for different CVD processes for TF mostly based on silicon dioxide. We characterized 
автором с помощью предложенной им характеристики "эффективная константа скорости процесса ХОГФ, $\mathrm{k}_{\mathrm{eff}}$ ". Выражение для $\mathrm{k}_{\mathrm{eff}}$ (размерность см/с) опре-

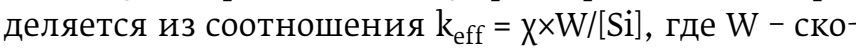
рость наращивания TП, [Si] - концентрация кремниевого компонента в газовой фазе, $X$ - коэффициент пропорциональности. Детальные пояснения по выводу соотношений могут быть найдены в [2]. Величины $\mathrm{k}_{\mathrm{eff}}$ для известных процессов ХОГФ кремнийсодержащих ТП обнаружили различие почти на три порядка величины [4]. Автором была показана эмпирическая количественная взаимосвязь конформности осаждения и $\mathrm{k}_{\mathrm{eff}}$ в виде соотношений: $\mathrm{d}_{2} / \mathrm{d}_{1}(\%) \sim 45,4 \times \mathrm{k}_{\mathrm{eff}}{ }^{-0,51}$. Медленные процессы с лимитирующими гетерогенными стадиями (малые $\mathrm{k}_{\mathrm{eff}}$ ) позволяют достичь максимальной, близкой к $100 \%$, конформности осаждения ТП. Напротив, активированные высокоскоростные процессы ХОГФ (большие $\mathrm{k}_{\mathrm{eff}}$ ) обнаружили неудовлетворительную конформность ТП.

Обработка экспериментальных данных для пустот в вертикальных прямоугольных канавках тестовых структур ИМС с Н 0,25...1,1 мкм и G 0,1...1,1 мкм проводилась автором с использованием РЭМ. Определялись критические точки $\left(\mathrm{AR}_{\text {crit }}, \mathrm{G}_{\text {crit }}\right)$ на графике в координатах AR - G [4-6], см. пример на рис.3. При анализе структур с различными величинами Н построение аналогичных графиков позволяет установить набор критических точек, через которые можно проводить прямые линии. Области ниже прямых линий соответствуют конформному, а области выше - неконформному осаждению ТП на исследуемом рельефе. В этом случае тангенс угла наклона прямых отражает способность исследуемого процесса ХОГФ ТП к заполнению рельефа ИМС с известными характеристиками при конкретных экспериментальных условиях.

Величину тангенса угла наклона автором было предложено называть параметром "сложность структур" (Structure Complexity, $\mathrm{SC}_{\text {crit }}=\mathrm{AR}_{\text {crit }} / \mathrm{G}_{\text {crit }}=\mathrm{H}_{\text {crit }} / \mathrm{G}_{\text {crit }}{ }^{2}$, размерность мкM $\left.^{-1}\right)$. В итоге проведенных анализа и обобщений оказалось возможным связать сложность структур ИМС c $\mathrm{k}_{\mathrm{eff}}$ процессов ХОГФ следующим соотношением: $\mathrm{SC}_{\mathrm{crit}} \sim 3,03 \times \mathrm{k}_{\mathrm{eff}}{ }^{-1,47}$. При этом важно, что параметр SC также применим для характеристики сложности исходных структур (до осаждения ТП). Действительно, при известных величинах H, G и AR, сложность структуры можно выразить как SC $\mathrm{Struct}_{\text {. }}$ Сопоставление величин $\mathrm{SC}_{\text {struct }}$ и достигнутых на практике величин $\mathrm{SC}_{\text {crit }}$ позволяет сравнивать задачи и реальные возможности исследуемого процесса ХОГФ. К сожалению, получение графиков, аналогичных приведенным на рис.3, довольно трудоемко и затратно как с точки зрения изготовления структур для исследований, так и с точки зрения необходимости использования РЭМ с хорошим разрешением. В связи с этим, по мнению автора, для проведения оценок возможностей методов ХОГФ вполне допустимо использовать величину $\mathrm{SC}_{\text {crit }}$, экспериментально полученную для одной точки.

Дальнейшее развитие технологий ИМС привело к появлению рельефов с глубокими канавками, уменьшенными линейными размерами G (до 0,02 мкм) и, таким образом, со значительно большими (до 100) аспектными отношениями (см. анализ в работе [8]). Для таких структур с повышенной deposition processes quantitatively using "effective constant of growth rate" for CVD proposed by author, called $k_{e f f}$. The expression for $k_{e f f}$ (dimension is $\mathrm{cm} / \mathrm{s}$ ) is determined from $\mathrm{k}_{\mathrm{eff}}=\chi \times \mathrm{W} /[\mathrm{Si}]$, where $\mathrm{W}$ - rate of TF growth, [Si] - concentration of Si-component in the gas phase, $X$ - proportionality factor.

See detailed explanations concerning these expressions in [2]. Values of $\mathrm{k}_{\text {eff }}$ for known CVD processes in case of silicon-based TF have shown the difference of more than three orders of value [4]. It was proved by the author that quantitative interrelation between conformity of deposition and $k_{\text {eff }}$ may be presented as: $d_{2} / d_{1}(\%) \sim 45,4 \times k_{\text {eff }}{ }^{-0,51}$. Slow processes with rate-controlling heterogeneous stages (small $\mathrm{k}_{\mathrm{eff}}$ ) allow of distinguishing the maximum, close to $100 \%$ value of TF deposition conformity. On the contrary, the activated high-rate CVD processes (high $\mathrm{k}_{\text {eff }}$ ) present the unacceptable conformity of TF.

We have treated the experimental data for voids in the vertical rectangular grooves of IMC testing structures with $\mathrm{H} \sim 0,25 . . .1,1 \mu \mathrm{m}$ and G 0,1...1,1 $\mu \mathrm{m}$ using SEM. Critical points $\left(A_{\text {crit }}, G_{\text {crit }}\right)$ on curve in coordinates AR - G [4-6] have been found (see an example on Fig.3). When analyzing the structures with different values of $\mathrm{H}_{\text {plot- }}$ ting of similar graphs can help to determine the critical points set and gives the possibility to draw straight lines through these points. So, the fields under straight lines correspond to conformity deposition of TF, above - nonconformity deposition on the studied relief. In this case, the tangent of the angle of inclination of the straight lines reflects the ability of the investigated CVD process for TF to fill the relief of IMC with known characteristics under specific experimental conditions.

We proposed to call tangent of the angle of inclination as a 


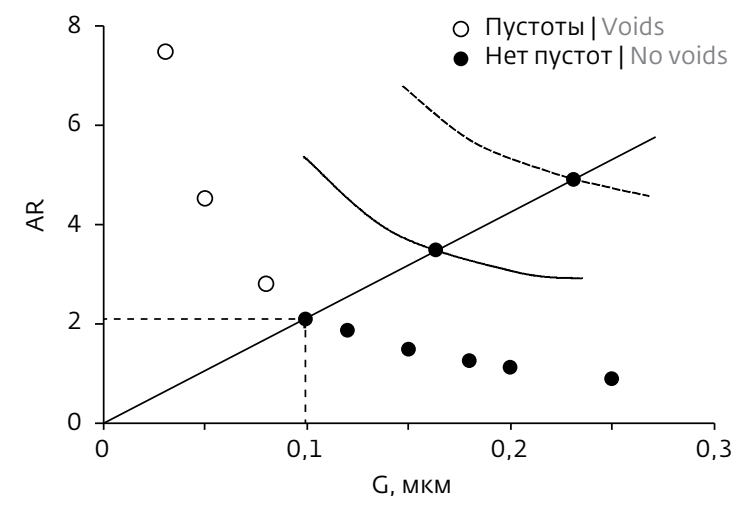

Pис.3. Пример определения критических величин $\mathrm{G}_{\text {crit }}=0,1$ мкм и $A R_{\text {crit }}=2$ (показаны пунктирами), соответствующих заполнению рельефа в ИМС без пустот [5] при разных веиичинах высоты канавки (H3> H2>H1). Тангенс угла наклона прямой соответствует $\mathrm{SC}_{\text {crit }}$

Fig.3. An example illustrating determination of the critical values of $G_{\text {crit }}=0.1 \mu \mathrm{m}$ and $A R_{\text {crit }}=2$ (shown dashed) which correspond to filling of the relief in IMC without voids [5] at different values of groove height $(\mathrm{H} 3>\mathrm{H} 2>\mathrm{H} 1)$. The tangent of angle inclination corresponds to $\mathrm{SC}_{\text {crit }}$

сложностью неконформность ТП для применяемых в то время процессов ХОГФ приводила к пустотам внутри структур (см. рис.2c), т.е. $\mathrm{SC}_{\text {crit }}<\mathrm{SC}_{\text {srtuct }}$. Для решения обозначенных проблем в начале 2000-х годов начали активно исследовать и использовать метод т.н. термоактивированного "атомно-слоевого осаждения, ACO" (Atomic Layer Deposition, ALD) [9]. Достоинство метода, строго говоря, являющегося вариантом ХОГФ, состоит в возможности локализации химической реакции формирования ТП строго на поверхности нагретых объектов. Локализация имеет место в узком температурном интервале, называемом "ALD-window". Применение ACO позволило для некоторых ТП и на некоторое время решить проблемы при работе со структурами повышенной сложности, однако по мере дальнейшего развития технологий ИМС и дальнейшего усложнения структур актуальность проблемы все время присутствует.

\section{МЕТОДЫ КОНТРОЛЯ КОНФОРМНОСТИ ТП И ПОСТАНОВКА ЗАДАЧИ}

Для исследований конформности ТП большинство авторов использовали тестовые структуры типа "канавка" (или "отверстие"), рис.2b, изготовленные по обычным микроэлектронным технологиям (описание структур и методологию анализа можно найти в [2,4-6]). Вертикальность стенок структур очень важна для анализа, т.к. для канавок с обратным наклоном получение конформных покрытий невозможно, а в канавках с наклонными стенками конформность осаждения ТП очень высока. Однако ввиду различия наклонов стенок рельефа исходных структур у разных авторов систематизировать дан ${ }^{-}$ ные для структур с наклонными стенками на практике сложно.

В развитие подхода [4-7] автор с соавторами в работе [8] предложил методику анализа "structure complexity" parameter (Structure Complexity, $\mathrm{SC}_{\text {crit }}=$ $\mathrm{AR}_{\text {crit }} / \mathrm{G}_{\text {crit }}=\mathrm{H}_{\text {crit }} / \mathrm{G}_{\text {crit }}{ }^{2}$, dimension is $\left.\mu \mathrm{m}^{-1}\right)$. As a result of the analysis and generalizations, it was possible to relate IMC structure complexity with $\mathrm{k}_{\mathrm{eff}}$ of CVD process according to the following expression: $\mathrm{SC}_{\text {crit }} \sim 3,03 \times \mathrm{k}_{\text {eff }}{ }^{-1,47}$. It is important that SC parameter can be applied to characterize structure complexity of initial structures (before TF deposition). Indeed, if $\mathrm{H}, \mathrm{G}$ and AR values are known, the structure complexity can be expressed as $\mathrm{SC}_{\text {struct }}$. Correlation of $\mathrm{SC}_{\text {struct }}$ value and the experimentally obtained $\mathrm{SC}_{\text {crit }}$ allows of comparing the tasks and real possibilities of the studied CVD process. Unfortunately, plotting graphs similar to those shown in Fig. 3 is quite laborious and expensive, both in terms of producing structures for research and in terms of the need to use SEM of high resolution. In author's opinion, in order to make an estimation of CVD methods possibilities it is permissible to operate with $\mathrm{SC}_{\text {crit }}$ value obtained experimentally for one point. Further development of IMC technologies led to the emergence of reliefs with deep grooves, reduced linear dimensions $G$ (down to $0.02 \mu \mathrm{m}$ ) and, thus, with much larger (up to 100) aspect ratios (see the analysis in [8]). The unconformity of TF in such complicated structures during CVD process have led to appearance of voids inside of these structures (see Fig.2b, i.e. $\mathrm{SC}_{\text {crit }}<$ $\left.\mathrm{SC}_{\text {srtuct }}\right)$. To solve these problems in the early 2000s, the researched began to actively explore and use the method of so-called "thermally activated atomic layer deposition" (ALD) [9]. The advantage of the method, strictly speaking, which is a variant of CVD, makes it possible to localize the chemical reaction of TF formation strictly on the surface of heated objects. Localization takes place in a narrow temperature range, called "ALD-window". The use of ALD has 


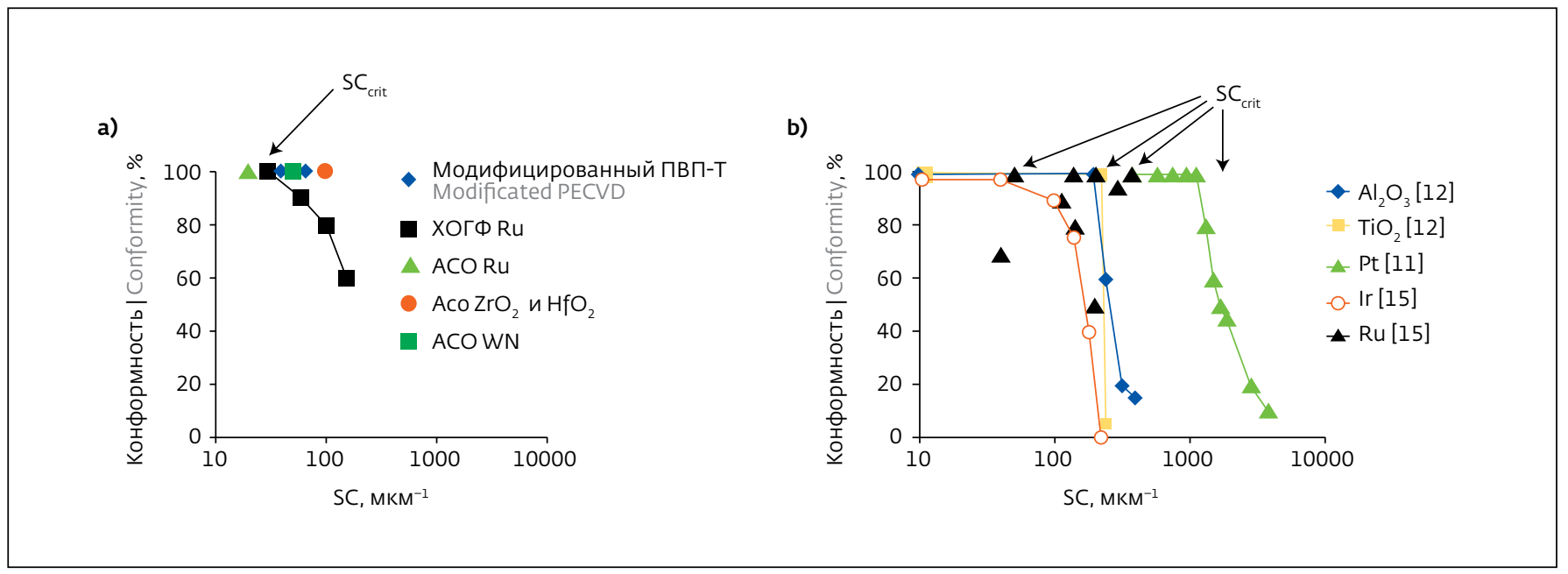

Pис.4. Взаимосвязь конформности роста ТП и сложности структуры по данным источника [9] (a) и по данным питературы $[11,12,15]$ (b). Данные для ТП оксида алюминия пересчитаны из данных рис.5а, для ТП платины - из данных рис.5b Fig.4. Interrelation between TF growth conformity and complexity structure according to [9] (a) and published data [11,12,15] (b). Data for TF of aluminum oxide was re-calculated from the data of Fig.5a, platinum - from data of Fig. $5 \mathrm{~b}$

конформности осаждения для процессов ХОГФ и АСО, приняв за основу параметр $\mathrm{SC}_{\text {crit }}$. Немногочисленные на время публикации экспериментальные данные по конформности для структур с известными размерами было предложено отображать в виде графика в координатах $\mathrm{d}_{2} / \mathrm{d}_{1}-\mathrm{SC}$. Пересчитанные по методике автора примеры для различных ТП при АСО на рис.4а указывают на $100 \%$ конформность для структур с $\mathrm{SC}_{\text {crit }}$ 20...100. Однако на примере процесса ХОГФ металлического рутения обнаружилось, что при некоторых величинах сложности структур начиналось систематическое ухудшение конформности (см. кривую на рис.4а). Точка отклонения величины конформности от $100 \%$ соответствует по смыслу критическим величинам SC на рис.3 и также была обозначена как $\mathrm{SC}_{\text {crit. }}$. Однако систематических данных по снижению конформности для АСО ТП на сложных структурах на тот период времени в литературе найдено не было.

K настоящему времени предприняты многочисленные исследования процессов АСО различных материалов и их свойств. Методы АСО совершенствуются, например, используется прямая или удаленная allowed for some types of TF and for some period of time to solve problems when working with structures of increased complexity, but with the further development of IMC technologies and complication of structures, the relevance of the problem is still present.

\section{METHODS OF THIN FILMS CONFORMITY CONTROL AND FORMULATION OF THE PROBLEM}

Most authors use testing structures like "groove" (or "hole") prepared by conventional microelectronic technologies (see Fig.2b) to study the TF conformity (description and methodology of the analysis see in
[2,4-6]). Verticality of the walls of the structures is very important for analysis, because it is impossible to obtain conformal coating for grooves with a backward slope, and in grooves with inclined walls, the conformity of TF deposition is very high. However, due to a difference in the wall slopes of the original structure relief as reported by different authors, it is difficult to classify the data for structures with inclined walls in practice.

Developing this approach [4-7], the author and co-authors in [8] proposed a method for analyzing conformity of deposition for the CVD and ALD processes, taking the $\mathrm{SC}_{\text {crit }}$ parameter as the basis. It was proposed at the time to plot the experimental data presented in a few publications as a chart with coordinates $\mathrm{d}_{2} / \mathrm{d}_{1}-\mathrm{SC}$. We have calculated examples of different TF prepared by ALD and have shown the result in Fig.4a. The obtained curves prove that structures with $\mathrm{SC}_{\text {crit }} \sim 20 . . .100$ have the conformity of $100 \%$. However, it was discovered, that in case of metallic ruthenium obtained with CVD process at some values of structure complexity the systematic conformity declined (see Fig.4a). The point of deviation of the conformity value from $100 \%$ corresponds, in a sense, 
плазма для активации одного из реагентов, используются последовательности напуска окислительных и восстановительных компонентов реакции, предлагаются обработки поверхности для улучшения нуклеации осаждаемого материала на поверхности, и т.д. Общее число публикаций превышает несколько тысяч, имеется ряд обобщений по АCO, см., например, [10].

Вместе с тем, целенаправленных публикаций по проблемам исследования конформности ТП при АСО немного. Обычно сведения о конформности ТП приводятся в публикациях в составе другой информации, и отображаются в виде демонстрационных РЭМ-фотографий структур, похожих на схематически приведенную на рис.2с. Для таких структур обычно указываются толщины ТП в верхней и нижних частях канавок/отверстий. В некоторых публикациях данные по конформности приводились для некоторых глубин канавки, например, на верхней, центральной и нижней частях структур. Выводами таких публикаций является информация о достигнутой величине AR для структур определенного размера G, на которых имеет (или не имеет) место 100\% конформность осаждения. Авторам работы [11] (единственной на настоящий момент времени) удалось по точкам построить профиль распределения толщины ТП металлической платины в вертикальном отверстии высотой 3,8 мкм и диаметром 0,023 мкм, см. рис.5а. Из данного графика можно видеть, что близкое к конформному осаждение для использованного метода АСО имеет место до глубины в канавке $\sim 0,5$ мкм, после чего толщина ТП быстро падает.
Вертикальные наноразмерные высокоаспектные структуры сложны в изготовлении и анализе и, в итоге, - затратны, хотя, как правило, однозначно соответствуют реальным структурам приборов. В связи с этим недавно предложены и на практике использованы т.н. плоские "горизонтальные" тестовые структуры (см. рис.2d). Такие "щелевые" тестовые структуры (далее называемые микрострукту рами) могут иметь линейные размеры Н до нескольких сотен микрон [12,13] и G до 0,5 мкм. В работе [14] описаны тестовые структуры с размерами до десятков миллиметров и зазорами до нескольких миллиметров (далее называемые макроструктурами). Плоские горизонтальные структуры представляют собой основу с подпорками и крышку. После осаждения ТП крышка удаляется, а распределение толщины ТП на дне плоской структуры (которое фактически является аналогом стенки вертикальной канавки) может контролироваться как визуально, так и с помощью общепринятых методов измерения толщины ТП. В результате оказывается возможным регистрировать профили толщин вдоль стенки (см. пример на рис.5b). Конечной целью использования горизонтальных щелевых структур является попытка прогнозирования закономерностей роста ТП в наноструктурах.

В настоящее время накапливаются экспериментальные данные для анализа и обобщение результатов по проблематике конформности получения покрытий на высокоаспектных структурах. При анализе проблем конформности роста ТП при АСО одной из важнейших задач автору представляется to the critical values of SC in Fig.3, and was also designated as $\mathrm{SC}_{\text {crit }}$. However, systematic data on the reduction of conformity for TF ALD on complex structures at that time was not found in the literature. By present time there were many studies of ALD processes for various materials and their properties. ALD methods are improved, for example, direct or remote plasma is used to activate one of the reagents, sequences of oxidation and reduction components of the reaction are used, surface treatments are proposed to improve nucleation of the deposited material on the surface, etc. The total number of publications exceeds several thousand; there is a number of generalizations on ALD (see, for example, [10]).

Along with that, publications dedicated to investigation of TF conformity obtained by ALD method are few. Usually, authors supply data about TF conformity as a part of other information and present it as demo slides of the photos obtained using scanning electron microscopy (SEM), schematically shown in Fig.2b. As a rule, a thickness of TF in upper and lower parts of grooves or holes for such structures have been indicated. In some cases a data for a few groove depths conformity had been given for upper, central or lower parts of the structures only. Authors of these publications conclude that AR value for the structures of certain size (G) where deposition conformity is equal to $100 \%$ (or not) has been achieved. Only in [11] the profile of metal platinum TF thickness distribution in a vertical hole of 3.8 $\mu \mathrm{m}$ and dia. of $0.023 \mu \mathrm{m}$ has been drawn as a point-to-point graph. It was shown that deposition close to conformity with the use of ALD method may be obtained up to the groove depth of $\sim 0.5 \mu \mathrm{m}$, after that a TF thickness rapidly decreases. 
a)

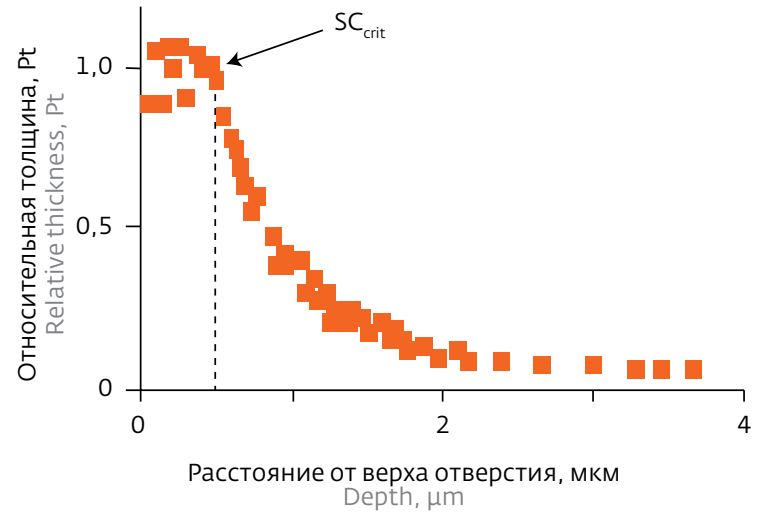

6)

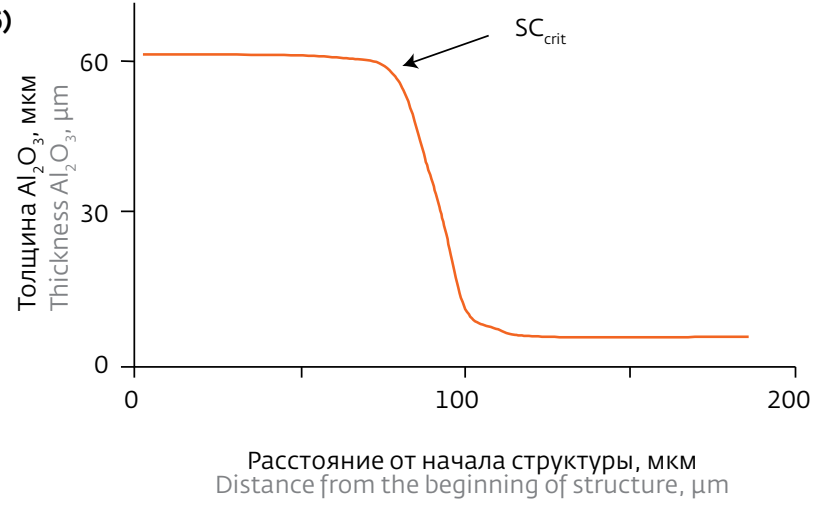

Рис.5. Изменение профиля толщины ТП по глубине тестовых структур для осажденных пленок платины на вертикальной тестовой структуре-отверстии (a) и оксида алюминия в горизонтальной тестовой структуре (b) методами АСО (по данным публикаций [11] и [12], соответственно)

Fig.5. Changes of TF thickness profile on test structure depth for deposited platinum films on the vertical testing structure- hole (a) and aluminum oxide in the horizontal test structure (b) using ALD methods (according to [11] and [12] correspondingly)

адекватная интерпретация экспериментальных данных для различных типов ТП, при различных экспериментальных условиях, на различных по конструкции тестовых структурах. Автор поставил задачу поиска простых количественных подходов, применимых к анализу экспериментальных результатов для сильно различающихся экспериментальных условий. Приведенный материал является развитием ранее апробированного подхода для анализа конформности ТП на рельефах ИМС при АСО [8].

\section{ОПИСАНИЕ ПРЕДЛАГАЕМОГО ПОДХОДА И ИНТЕРПРЕТАЦИЯ РЕЗУЛЬТАТОВ}

В высокоаспектных структурах при АСО имеет место заполнение канавок и отверстий по типу приведенного на рис.2с - при неконформном осаждении внутри структур образуются пустоты. Для некоторых практических задач это может быть приемлемо, однако в большинстве случаев для современных приборов считается недопустимым. Развивая подход анализа величин $\mathrm{SC}_{\text {crit }}$ (рис.4a), литературные данные для таких высокоаспектных канавок (отверстий)
Vertical nanoscale high aspect structures are difficult to produce and analyze and, due to this fact, very expensive, although, it corresponds well for real device structures. Recently proposed and applied practically were so called flat "horizontal" testing structures (see Fig.2d). These "gap" testing structures (hereinafter called microstructures) may have linear dimensions $\mathrm{H}$ up to some hundred micrometers $[12,13]$ and $G$ about $0.5 \mu \mathrm{m}$. In [14] testing structures with dimensions of up to tens millimeters and gaps about some millimeters (hereinafter called macrostructures) were described.
Flat horizontal structures present a base with supports and a cover. After TF deposition a cover is removed and distribution of $\mathrm{TF}$ thickness in a bottom of the structure (which is, practically, the analog of a vertical groove wall) can be controlled both visually and by conventional control methods. As a result, it is possible to register the profiles of thickness along the wall (see an example in a Fig.5b). The final aim of horizontal gap structures is the attempt to predict TF growth regularities in nanostructures.

Presently the experimental data for analysis and generalization of the results pertaining to conformity problems connected with coatings of high aspect structures are being collected. While analyzing TF conformity at ALD process, the one of the most important goals is the adequate interpretation of the experimental data for different types of thin films and under various experimental conditions on diverse types of testing structures.

We set the problem of finding simple quantitative approaches applicable to analysis of the experimental results for quite different experimental conditions. The supplied material presents a 
также могут быть пересчитаны из известных дан ных по AR и G в величины SC. Примеры такого отображения результатов в координатах $\mathrm{d}_{2} / \mathrm{d}_{1}(\%)-\mathrm{SC}$ показаны на рис.4b. Для ТП металлического рутения данные приведены в виде отдельных точек (отметим, что применялись различные прекурсоры рутения и условия АСО [15]). Можно видеть, что конформность в ряде случаев существенно меньше желаемой (100\%). При этом по отдельным экспериментальным точкам с $\mathrm{d}_{2} / \mathrm{d}_{1}<100 \%$ невозможно оценить величину $\mathrm{SC}_{\text {crit }}$, для которой было бы возможно достичь реальную 100\% конформность осаждения ТП примененным методом АСО.

В более интересном случае, когда авторами приводятся данные величин конформности по глубине канавок, перерасчет позволяет отобразить реальные тренды и определить величины $\mathrm{SC}_{\text {crit }}$. Действительно, профили толщины в канавках/отверстиях также можно пересчитывать в зависимость $\mathrm{d}_{2} / \mathrm{d}_{1}(\%)-\mathrm{sc}$, (см. рис.5a,b). При нормировке в процентах текущей величины толщины ТП на таковую при координате "0" (начало канавки, считая от входа реагентов) получаем параметр "конформность, \%". Текущую координату (i) глубины вертикальной канавки или точки на сканах толщины в горизонтальных микроструктурах, фактически являющуюся $\mathrm{H}_{\mathrm{i}}$, легко для известных величин $\mathrm{G}$ трансформировать в величину $\mathrm{AR}_{\mathrm{i}}$ и $\mathrm{SC}_{\mathrm{i}}$. Результаты такого перерасчета показаны на рис.4b на примере четырех различных ТП материалов в виде кривых с индикацией величин $\mathrm{SC}_{\text {crit }}$. Кривые для $\mathrm{Al}_{2} \mathrm{O}_{3}$, $\mathrm{TiO}_{2}$ и металлического иридия были получены с использованием плоских структур. Можно видеть, что максимальные значения для них составляют $\mathrm{SC}_{\text {crit }}-200 \mathrm{mKM}^{-1}$. Интересно отметить, что согласно рис.4b максимально возможные по сложности структуры SC $_{\text {crit }}-1100$ мкм $^{-1}$ были получены при использовании в качестве второго реагента озона [11], который в последние годы рассматривается перспективным реагентом для получения металлических ТП при ACO.

В целом тренды кривых на рис.4b соответствует таковому на рис.4а для процесса ХОГФ ТП металлического рутения, опубликованному в [8]. В связи с этим предложенный ранее подход анализа конформности роста ТП на рельефах с помощью зависимостей $\mathrm{d}_{2} / \mathrm{d}_{1}(\%)$ - SC представляется для анализа процессов ACO ТП непротиворечивым. Он дает возможность переходить от специфических размеров тестовых структур к унифицированной величине их сложности $\left(\mathrm{SC}_{\text {struct }}\right)$ и оценивать для любых размеров микроструктур их способность быть заполненной ТП материалами с высокой степенью конформности ( $\left.\mathrm{SC}_{\text {crit }}\right)$.

В настоящее время имеется немного экспериментальных данных для наноразмерных структур, и однозначная оценка применимости предложенного подхода к их описанию еще предстоит в будущем. Тем не менее, поскольку по мере заполнения канавок ТП их размер G уменьшается вплоть нуля, то есть - до полного смыкания растущих фронтов ТП, эти эффекты присутствуют и на уровне микроструктур. В связи с этим автор предполагает возможность и адекватность применения предлагаемой методики и для наноструктур. development of the earlier timetested approach to analysis of TF conformity on the IMC reliefs ALD [8].

\section{DESCRIPTION OF THE PROPOSED APPROACH AND INTERPRETATION OF THE RESULTS}

In high aspect structures prepared by ALD method the grooves and holes are filled as it is shown in Fig.2b, where voids are formed inside these structures at non-conformity deposition. For some practical goals it is possible, but in the majority of cases it is inadmis sible. To develop the approach to analyzing $\mathrm{SC}_{\text {crit }}$ values (see Fig.4a), the data presented in publications for such high aspect grooves (holes) can be re-calculated based on the known data of AR and G, and SC values. Examples of such re-calculation in $d_{2} / d_{1}(\%)-S C$ coordinates are shown in Fig.4b. The data for metal ruthenium are shown as separate dots (it should be remarked that different precursors of ruthenium and ALD conditions [15] were used). It was shown that conformity in some cases is definitely lower than the desirable one $(100 \%)$. In that case we cannot to determine the $\mathrm{SC}_{\text {crit }}$ value using experimental dots with $\mathrm{d}_{2} / \mathrm{d}_{1}<100 \%$ in order to achieve the $100 \%$ real deposition of TF conformity using the ALD method.

When authors present more interesting cases concerning the data on conformity values for groove depths, the re-calculation makes it possible to see real trends and to determine the $\mathrm{SC}_{\text {crit }}$ values. Indeed, the profiles of depth in grooves/holes can be re-calculated and presented as the dependence of $d_{2} / d_{1}(\%)-S C$, (see Fig. 5b). When we normalize the current value of TF thickness to the zero coordinate (the beginning of a groove, starting from reagents input), we obtain the conformity parameter in percentage. Afterwards the current 
Что касается макроструктур, то для них обработка данных [14], по предложенной методике, дает аналогичные тренды, но абсолютные величины сложности таких структур оказываются на 4-6 порядков меньше, чем для микро- и наноструктур. В связи с этим в настоящее время остается открытым вопрос о применимости результатов для таких структур при прогнозировании конформности наноструктур. Вместе с тем такие легко изготавливаемые и дешевые структуры оказываются очень удобными для отслеживания трендов роста ТП в щелевых структурах, в том числе - для экспресс-контроля процессов.

\section{ВЫВОДЫ}

Приведенные в работе и литературные данные позволяют очертить области конформного осаждения ТП при использовании различных методов осаждения из газовой фазы, см. рис.6. Наклонные участки областей справа условны и отображают в общем виде тренд к снижению конформности при $\mathrm{SC}_{\text {struct }}>\mathrm{SC}_{\text {crit }}$. Приведенные данные однозначно показывают преимущества методов АСО с точки зрения конформности получаемых ТП в высокоаспектных наноразмерных структурах с максимальными величинами $\mathrm{SC}_{\text {crit }}$. Предложенный подход даже по единичным литературным данным позволяет проводить сравнительную оценку параметров заполнения структур теми или иными методами получения ТП покрытий для исходных структур с известными параметрами.

Предложенный автором подход позволяет для высокоаспектных наноразмерных структур различной сложности проводить адекватную оценку

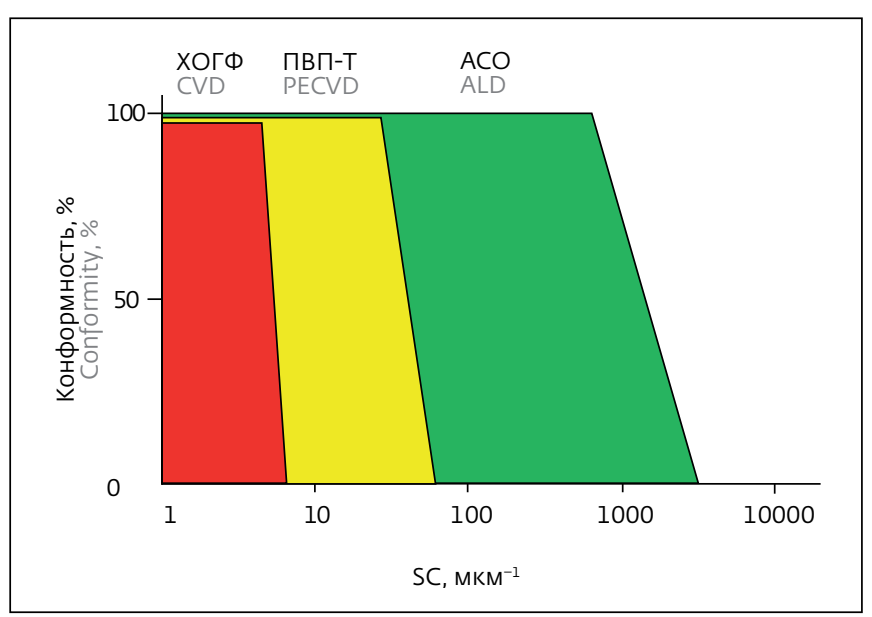

Рис.6. Примерные области эффективного использования методов ХОГФ, осаждения с плазмой высокой плотности и одновременным травлением (ПВП-Т), атомно-слоевого осаждения, связывающие конформность осаждения и сложность структур

Fig.6. Approximate fields showing effective use of CVD, PECVD with simultaneous etching and ALD methods which bind deposition conformity and structure complexity

и количественное сравнение конформности роста тонких пленок для различных вариантов и режимов получения тонких пленок методом АСО.

\section{ЛИТЕРATУPA / REFERENCES}

1. Handbook of Semiconductor Manufacturing Technology, second edition. Ed. By R. Doering and Y. Nishi // CRC press, 2008, 1722 pages. coordinate (i) of the vertical groove depth or point in a thickness scans for horizontal microstructures (in fact, $\mathrm{H}_{\mathrm{i}}$ ) may be easily transformed into $\mathrm{AR}_{\mathrm{i}}$ and $\mathrm{SC}_{\mathrm{i}}$ values for known $\mathrm{G}$ value. The results of this re-calculation are shown in a Fig.4b for four different TF materials as curves which indicate values of $\mathrm{SC}_{\text {crit }}$. The curves of $\mathrm{Al}_{2} \mathrm{O}_{3}, \mathrm{TiO}_{2}$ and metal iridium were obtained using flat structures. It can be seen that the maximum values for them are $\mathrm{SC}_{\text {crit }}-200$ $\mu \mathrm{m}^{-1}$. It is interesting to note that, according to Fig.4b, the maximum possible structures of $\mathrm{SC}_{\text {crit }}$-1100 $\mu \mathrm{m}^{-1}$ were obtained when ozone was used as the second reagent [11], which in recent years has been considered a promising reagent for the production of metal TF in ALD process. Generally, trends in Fig.4b correspond to the data shown in Fig.4a for TF of metal ruthenium obtained by CVD method and published in [8]. Based on these data, the earlier proposed approach for analysis of conformity TF growth on the reliefs using dependencies like $d_{2} / d_{1}(\%)$ - SC seems to be consistent for ALD process in case of thin films. This approach makes it possible to move from specific testing structure sizes to the unified value of their complexity $\left(\mathrm{SC}_{\text {struct }}\right)$ and estimate their possibility to be filled with TF materials for any conformity value $\left(\mathrm{SC}_{\text {crit }}\right)$ and for any size of microstructures. Currently, there are few experimental data for nanoscale structures, and an unambiguous assessment of the applicability of the proposed approach to their description is still to be done in the future. However, as the grooves of the TF are filled, their size G decreases down to zero, that is, until the closing fronts of the TF are fully closed, these effects are also present at the level of microstructures. In this regard, the author suggests a possibility and adequacy of the application 
2. Vasilyev V.Yu. Thin Film Chemical Vapor Deposition in Integrated Circuit Technology: Equipment, Methodology and Thin Film Growth Experience / Nova Science Publishers, Inc.: New York. 2014. 314 pages.

3. Васильев В.Ю. Тренды развития методов химического осаждения из газовой фазы тонкопленочных материалов для прецизионных технологий // Нано- и микросистемная техника. 2014. № 9 (170). С. 37-44.

4. Васильев В.Ю. Тенденции развития технологии и аппаратуры химического осаждения тонких диэлектрических слоев на основе диоксида кремния в микроэлектронике. Часть 2. Заполнение узких зазоров осажденным материалом // Микроэлектроника, 1999,. Т. 28., № 3. - С. 183-192.

5. Vassiliev V.Yu., Lin C., Fung D., Hsieh J., and Sudijono J.L. Properties and gap-fill capability of high-density plasma chemically vapor deposited phosphosilicate glass films for subquarter micrometer ULSI device technology // Electrochem. Solid State Letters, 2000, vol.3, N2, p.p.80-83.

6. Vassiliev V.Y., Sudijono J.L., and Cuthbertson A. Trends in Void-Free Pre-Metal CVD Dielectrics // Solid State Technol. 2001. V. 44. N 3. P. 129-136.

7. Васильев В.Ю. Заполнение ультрамалых зазоров в интегральных микросхемах осажденными из газовой фазы тонкими диэлектрическими материалами на основе диоксида кремния // Микроэлектроника. 2002. Т. 31. № 4. С. 263-273.

8. Vasilyev V.Yu., Chung S., Song Y.W. Quantifying ALD technology for High Aspect Ratio Structures // Solid State Technol. 2007. V. 50. N 8. P. 53, 54, 56.
9. Leskela M., Ritala M. Atomic layer deposition (ALD): from precursors to thin film structures // Thin Solid Films. 2002. V. 409., N 1-2, P. 138-146.

10. Johnson R.W., Hultqvist A., Bent S.F. A brief review of atomic layer deposition: from fundamentals to applications // Materials today. 2014. V.17, N.5. P. 236-246.

11. Dendooven J., Ramachandran R.K., DevlooCasier K., et al. Low-Temperature Atomic Layer Deposition of Platinum Using (Methylcyclopentadienyl)trimethylplatinum and Ozone // J. Phys. Chem. C, 2013, V. 117. , P. 20557-20561.

12. Puurunen R.L., Gao F. Influence of ALD Temperature on Thin film Conformality: Investigation with Microscopic Lateral HighAspect-Ratio structures // Proc. 14 ${ }^{\text {th }}$ Int. Baltic Conf. on Atomic Layer Deposition (BALD), 2016, St. Petersburg, Russia, paper \# 16774638, 5 pages.

13. Okada S., Matsumura H. Properties of CatCVD silicon nitride films and their application as passivation films // Proc. Mat. Res. Soc. Symp.1997. Vol. 446. P. 109-114.

14. Dendooven J., Deduytsche D., Musschoot J., et al. Conformality of $\mathrm{Al}_{2} \mathrm{O}_{3}$ and AlN Deposited by Plasma-Enhanced Atomic Layer Deposition // J. Electrochem. Soc., 2010,. V. 157. , N 4, P. G111-G-116.

15. Mattinen M., Hamalainen J., Gao F., et al. Nucleation and Conformality of Iridium and Iridium Oxide Thin Films Grown by Atomic Layer Deposition // Langmuir, 2016, Vol.32, N 41. P. 10559-10569. of the proposed methodology for nanostructures.

As concerns macrostructures, their data processing [14], according to the proposed method, gives similar trends, but the absolute values of the complexity of such structures turn out to be 4-6 orders of magnitude less than for micro and nanostructures. In this connection, the question of applicability of the results for such structures in predicting the conformity of nanostructures remains open. At the same time, such easily manufactured and cheap structures turn out to be very convenient for tracking the growth trends of TF in gap structures, including for express control of processes.

\section{CONCLUSIONS}

The data presented in the paper and the published data make it possible to delineate the areas of conformity deposition of TF using different methods of deposition from the gas phase, see Fig.6. Inclined sections of fields on the right are conditional and indicate the falling trend of conformity in general when $\mathrm{SC}_{\text {struct }}>$ $\mathrm{SC}_{\text {crit. }}$. The data presented unambiguously prove the advantages of ALD methods from the viewpoint of the obtained TF conformity in high aspect nanoscale structures with maximum $\mathrm{SC}_{\text {crit }}$ values. The proposed approach, though based on singular published data, allows of a comparative assessment of the parameters for filling structures with one or another method of obtaining TF coatings for initial structures with known parameters. The approach proposed by the author enables to adequately assess and numerically compare the growth conformity of thin films for high-aspect nanoscale structures of varying complexity, for various options and modes of thin film production using the ALD method. 


\section{d \\ АНАЛИТИКА экспо}

18-я Международная выставка лабораторного оборудования и химических реактивов

$21-24.04 .2020$

Москва, МВЦ «Крокус Экспо»

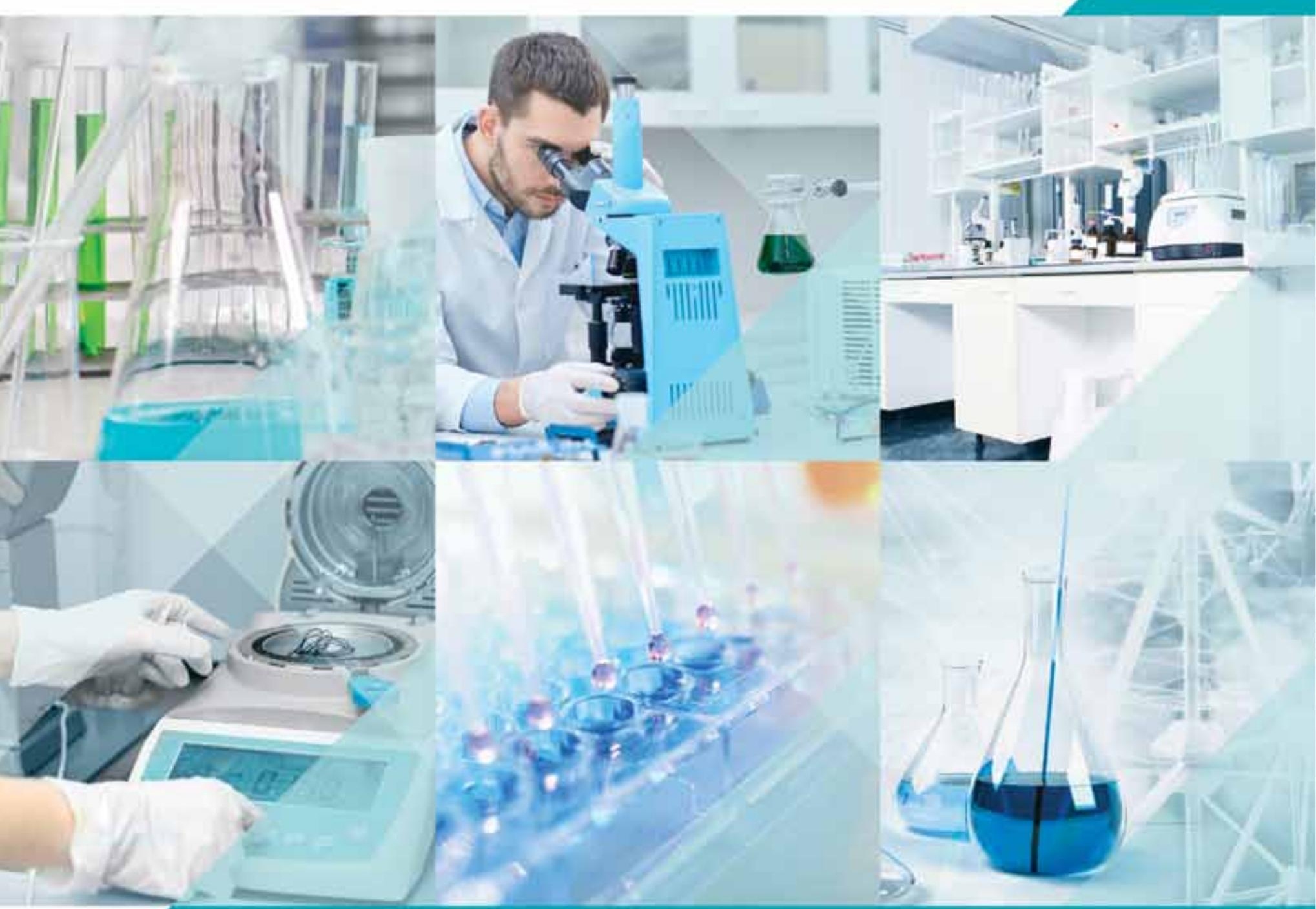

\section{analitikaexpo.com}

Забронируйте стенд 